\title{
Váltott múszakban dolgozó ápolók alvásminőségének vizsgálata a magyar nyelvre adaptált Bergen Shift Work Sleep Questionnaire alkalmazásával
}

\author{
Fusz Katalin ${ }^{1}$ - Tóth Ákos dr. ${ }^{3}$ - Fullér Noémi ${ }^{1}$ \\ Müller Ágnes ${ }^{2}$. Oláh András dr. ${ }^{1}$ \\ Pécsi Tudományegyetem, Egészségtudományi Kar, ${ }^{1}$ Ápolástudományi, Alapozó Egészségtudományi \\ és Védőnői Intézet, ${ }^{2}$ Sürgősségi Ellátási és Egészségpedagógiai Intézet, Pécs \\ ${ }^{3}$ Pécsi Tudományegyetem, Természettudományi Kar, Sporttudományi és Testnevelési Intézet, Pécs
}

\begin{abstract}
Bevezetés: A váltott múszakban dolgozóknál gyakori probléma a megzavart diurnalis ritmus következtében kialakuló alvászavar. A Bergen Shift Work Sleep Questionnaire az alvásminőséget és hatásait vizsgálja különböző műszakok és szabadnapok esetén. Célkitüzés: A tanulmány célja e kérdőív magyar változatának kidolgozása, és alkalmazásával a különböző munkarendben dolgozó ápolók alvásminőségének összehasonlítása. Módszer: A kérdőívet 326, váltott múszakban dolgozó ápoló töltötte ki. A kérdőív konvergens és diszkrimináns validálása az Athéni Insomnia Skála és Észlelt Stressz Kérdőív segítségével történt. Eredmények: A kérdőív pszichometriai jellemzői alapján magyar mintán is alkalmas a váltott múszakkal összefüggő alvászavarok vizsgálatára. A diszkrét tünetek gyakorisága szignifikánsan ( $\mathrm{p}<0,001)$ eltért a múszakok szerint. A legrosszabb alvásminőséget és nappali fáradtságot az éjszakai múszakot követően tapasztalták. A több mûszakos, szabálytalan munkarendben dolgozók alvásminősége rosszabb, mint a szabályos és flexibilis munkarendben dolgozóké $(\mathrm{p}<0,001)$. Következtetések: A váltott múszakos ápolók alvásproblémáit a kidolgozott kérdőívvel célszerú országosan, reprezentatív mintán is megvizsgálni, és az eredmények alapján a legkevésbé megterhelő munkarendeket kialakítani. Orv. Hetil., 2015, 156(49), 2003-2009.
\end{abstract}

Kulcsszavak: cirkadián ritmus, váltott múszak, éjjeli múszak, aluszékonyság, munkabeosztás

\section{Sleep quality of nurses working in shifts - Hungarian adaptation of the Bergen Shift Work Sleep Questionnaire}

Introduction: Sleep disorders among shift workers are common problems due to the disturbed circadian rhythm. The Bergen Shift Work Sleep Questionnaire assesses discrete sleep problems related to work shifts (day, evening and night shifts) and rest days. Aim: The aim of the study was to develop the Hungarian version of this questionnaire and to compare the sleep quality of nurses in different work schedules. Method: 326 nurses working in shifts filled in the questionnaire. The authors made convergent and discriminant validation of the questionnaire with the Athens Insomnia Scale and the Perceived Stress Questionnaire. Results: The questionnaire based on psychometric characteristics was suitable to assess sleep disorders associated with shift work in a Hungarian sample. The frequency of discrete symptoms significantly $(\mathrm{p}<0.001)$ differed with the shifts. Nurses experienced the worst sleep quality and daytime fatigue after the night shift. Nurses working in irregular shift system had worse sleep quality than nurses working in regular and flexible shift system $(\mathrm{p}<0.001)$. Conclusions: The sleep disorder of nurses working in shifts should be assessed with the Hungarian version of the Bergen Shift Work Sleep Questionnaire on a nationally representative sample, and the least burdensome shift system could be established. 
Keywords: circadian rhythm, shift work, sleepiness, irregular work schedule

Fusz, K., Tóth, Á., Fullér, N., Müller, Á., Oláh, A. [Sleep quality of nurses working in shifts - Hungarian adaptation of the Bergen Shift Work Sleep Questionnaire]. Orv. Hetil., 2015, 156(49), 2003-2009.

(Beérkezett: 2015. október 3.; elfogadva: 2015. október 22.)

\section{Rövidítések}

BSWSQ = Bergen Shift Work Sleep Questionnaire; BSWSQ-H = Bergen Váltott Músszak Alvás Kérdőív

A váltott múszakban dolgozóknál a biológiai ritmusok zavart szenvednek, vagyis belső deszinkronizáció alakul ki, amíg a szervezet belső órája nem alkalmazkodik a megváltozott körülményekhez [1, 2]. Ebben az esetben a megzavart diurnalis ritmus következtében gyakori probléma az alvászavar $[3,4,5]$. Insomnia, azaz alvási elégtelenség akkor áll fenn, ha az alvás megkezdődése és/vagy fenntartása zavart szenved, következményes nappali panaszokkal és életminőség-romlással. A váltott müszakban történő munkavégzés során fennálló, társbetegségek nélküli insomniás tünetek esetén cirkadiánritmus-zavarról beszélünk [6].

Számos, alvászavart mérő kérdőív létezik, azonban kifejezetten a váltott müszakban dolgozók müszakrendekhez köthető alvásproblémáit felmérő kérdőív kevés van. Folkard és mtsai [7] több kérdőívből állították össze a Standard Shiftwork Index (SSI) kérdöívcsomagot, amellyel a váltott múszakban dolgozók munkával kapcsolatos problémáit (mint szomatikus panaszok, alvászavar, kimerültség, élvezeti szerek alkalmazása, megküzdési probléma) mérték fel. Egy korábbi vizsgálatunkban mi is alkalmaztuk az SSI-t, amely során eredményül kaptuk, hogy a csak nappal dolgozó ápolók között kevesebben szenvednek alvászavarban és nappali fáradtságban, mint az éjszakai és váltott mûszakban dolgozók, továbbá jobb egészségi állapotról számoltak be [8].

A váltott múszakos munkához kapcsolódó alvászavart vizsgálták Flo és mtsai [9] ápolók körében $(\mathrm{n}=1968)$. Összefüggést találtak a váltott mûszakos munkához kapcsolódó alvászavar és az alábbi változók között: életkor, nem, cirkadián ritmus, szorongás, az előző évben átdolgozott éjszakák száma, valamint azok a múszakok, amikor kevesebb, mint 11 óra volt két müszak között. Flo és mtsai [10] a Bergen Shift Work Sleep Questionnaire-t (BSWSQ) azért fejlesztették ki, hogy feltárják a különböző műszakokhoz (nappali, esti, éjszakai) és a szabadnapokhoz kapcsolódó alvásproblémákat és következményeit, mint kialvatlanság, fáradtság. Validáló tanulmányukban a BSWSQ pszichometriai tulajdonságait értékelték egy 760 fős mintában, amelyben az összes ápoló három müszakos munkarendben dolgozott. Megvizsgálták a BSWSQ-modell illeszkedését és megbízhatóságát, valamint a konvergens és diszkrimináns vali- ditását az Epworth Sleepiness Scale, Fatigue Questionnaire, valamint a Hospital Anxiety Depression Scale segítségével. A BSWSQ kérdőív megbízhatónak bizonyult (a teszt-reteszt együttható szignifikanciaszintje $<0,001$ ) és jó konvergens és diszkrimináns validitást tapasztaltak a BSWSQ és a többi skála között (valamenynyi együttható esetében $\mathrm{p}<0,001)$. Az éjszakai múszakban volt a legmagasabb pontszám összehasonlítva a nappali és az esti múszakban, valamint a pihenőnapokon kapott pontokkal. Arra a következtetésre jutottak, hogy a BSWSQ megfelel a szükséges pszichometriai elóírásoknak, amelyek lehetővé teszik a diszkrét álmatlanság tüneteinek szisztematikus vizsgálatát különböző műszakokban.

Léteznek magyarra adaptált alvásminőséget, insomniát mérő skálák, például a Pittsburgh Sleep Quality Index [11], Athens Insomnia Scale [12], Epworth Sleepiness Scale [13, 14], Groningen Sleep Quality Scale [15]. Ezek azonban nem különböztetik meg a tünetek előfordulását müszakok, illetve pihenőnapok szerint, így kevésbé alkalmasak a váltott műszakkal összefüggésbe hozható alvásproblémák feltárására, mint a BSWSQ. Hazánkban a váltott műszakban dolgozók alvásminőségének felméréséről szóló közleményt nem találtunk, a Standard Shiftwork Indexet is mi alkalmaztuk elöször [7].

Jelen kutatásunk célja, hogy egzakt módszerekkel igazoljuk a különböző típusú ápolói munkarendek - mint nappali vs. éjszakai műszakok, illetve a müszakváltások szabályossága - és az alvásproblémák összefüggéseit. Keressük a legkevésbé megterhelő váltott múszakos múszakrendet. Kutatási eszközként a fenti szakirodalmak alapján a BSWSQ kérdőívet kívántuk alkalmazni, amelyet azonban Magyarországon még nem használtak, ezért első lépésként a kérdőív hazai viszonyokra történő adaptálását kellett elvégezni, azaz a kérdőív magyarra fordítását, továbbá validitásának pszichometriai módszerekkel történő ellenőrzését.

\section{Módszer}

\section{Minta}

Az adatfelvétel 2014-ben, különböző munkarendben dolgozó ápolók körében történt. A BSWSQ magyar változatát, a BSWSQ-H kérdőívet a Pécsi Tudományegyetem, Klinikai Központ, Szívgyógyászati Klinika, Szülészeti és Nőgyógyászati Klinika, Neurológiai Klinika, Pszichiátriai és Pszichoterápiás Klinika, valamint a Tolna 
Megyei Balassa János Kórház összes ápolójának bevonásával, továbbá országos szintü online felmérés keretében alkalmaztuk.

Az országos felmérés során hólabda módszert alkalmaztunk, az online kérdőívet ismerős ápolóknak küldtük ki az ország összes megyéjébe, hogy továbbítsák minél több ápolónak. Heves és Vas megye kivételével mindenhonnan érkezett kitöltött kérdőív.

Az összesen 447, értékelhető módon megválaszolt kérdőív kitöltője közül 326 fő dolgozik jelenleg váltott múszakban (114 a pécsi klinikákról és 212 az országos mintából beérkezettekből). A válaszolási arány $60 \%$ körül mozgott.

A válaszadók 93\%-a nő, átlagéletkoruk 39,9 év (SD: 9,8, minimum: 20, maximum: 66), átlagosan 16,4 éve (SD: 11,2) dolgoznak ápolóként.

A BSWSQ-H (Bergen Váltott Műszak Alvás Kérdőív) konvergens és diszkrimináns validálását a megkérdezettek köréből véletlenszerűen kiválasztott ápolói mintákon végeztük, akik a BSWSQ-H kérdőíven kívül kitöltötték az Észlelt Stressz Kérdőívet (Perceived Stress Scale PSS) [16] (n = 134), valamint közülük 77 fó az Athéni Insomnia Skálát (AIS) [12] is. A teszt-reteszt vizsgálatot egy további 22 fös almintán végeztük el 2 hét különbséggel.

\section{Méröeszközök}

Bergen Shift Work Sleep Questionnaire - BSWSQ [10]: Az általunk adaptálni kívánt kérdőív az alvásminőséget és annak ébrenlétre gyakorolt hatásait vizsgálja több mûszakos munkavállalóknál a különböző múszakokra és szabadságra vonatkozóan. A kérdések az álmatlanság és fáradtság/álmosság klinikai tüneteire kérdeznek rá a DSM-IV-TR (APA, 2000), ICSD-2 (AASM, 2005) és az ICS-10 (WHO, 1992) kritériumainak megfelelően. A kérdőív ötfokozatú (0-4) Likert-skálákat alkalmaz, amelyek az egyes panaszok gyakoriságát mérik. A magasabb pontértékek rosszabb alvásminőséget tükröznek. A különböző műszakokra, valamint részben a pihenőnapokra vonatkozón ugyanazokat a kérdéseket tettük fel, így összesen 23 kérdést (itemet) tartalmazott a teszt.

Athéni Insomnia Skála [12]: Nyolc kérdéséből az első öt az éjszakai tüneteket méri fel (elalvási és átalvási nehézség, korai felébredés), míg a többi a megzavart alvás nappali következményeire kérdez rá.

Észlelt Stressz Kérdöiv [16]: A kérdőív 14 tételt tartalmaz, amelyeket 5 fokozatú Likert-skálával (0-4) kell pontozni. Az egyes kérdéseknél a magasabb pontszámok a stresszhelyzetek nagyobb gyakoriságát és a sikeresebb megküzdést jelzik.

A röviditett Morningness-Eveningness Questionnaire (rMEQ) $[17,18]$ hat tétele a kronotípust vizsgálja, azaz, hogy reggeli (pacsirta) vagy esti (bagoly) típusú-e a válaszadó.
Müszakrendre vonatkozó kérdések: Saját szerkesztésü és a Standard Shiftwork Indexből [7] átvett kérdések, amelyek az ápolók munkarendjének szabályosságára, típusára vonatkoznak.

\section{Statisztikai elemzés}

A statisztikai elemzéseket az SPSS 20.0 programcsomaggal végeztük (SPSS, Chicago, IL).

Az alkalmazott kérdőívek belső reliabilitását Cronbach-alfával ellenőriztük. A BSWSQ-H kérdőív által lefedett dimenziókat faktoranalízissel ${ }^{1}$ tártuk fel (fókomponensanalízis módszerrel, varimax rotáció alkalmazásával). A BSWSQ-H egyes kérdéseire adott válaszok müszakonkénti összehasonlítását az összetartozó mintás varianciaanalízissel, a páronkénti összehasonlítást Bonferroni-korrekcióval végeztük. Pearson-féle korrelációs együtthatót számítottunk a konvergens és diszkrimináns validitás vizsgálatára, valamint a teszt-reteszt megbízhatóság mérésére. Független csoportok összehasonlítására (múszakrendek szabályossága) egyszempontos varianciaanalízist és (Scheffe-féle) post hoc tesztet alkalmaztunk. Az eredményeket mindegyik teszt esetén $p<0,05$-nál tekintettük szignifikánsnak.

\section{Eredmények}

\section{A Bergen Shift Work Sleep Questionnaire nyelvészeti szempontból történó validálása és a BSWSQ-H bemutatása}

2013-ban megkaptuk a BSWSQ szerzőjétől, Elisabeth Flo-tól az engedélyt és a kérdőívet angol nyelven. Három független személy fordította le a kérdőívet angolról magyarra. Az angol nyelvü kérdőívben az alábbi három müszak megnevezése szerepelt: „day shift/ordinary day work”, „evening shift/evening work” és „night shift/ night work", amelyek magyar nyelvben történő alkalmazása a módosítást követően az alábbi: nappali műszak, délutáni műszak és éjszakai mûszak. A magyar nyelvü kérdőív visszafordítását két független, „kétnyelvű” („bilingual”) fordító végezte. A fordításokat összevetve és a próbafelvételek tapasztalatai alapján alakítottuk ki azt a verziót, amellyel végül a kérdezést végeztük.

A BSWSQ-H validálását az eredeti koncepciónak megfelelően csak a jelenleg is váltott müszakban dolgozók körében végeztük el. Mivel nem minden kérdésre érkezett válasz az egyes kérdésekre adott válaszok müszakonkénti összehasonlítása során, illetve a BSWSQ-H összpontszámára vonatkozóan, a mintaelemszámok némileg különböznek egymástól.

Az önkontrollos ANOVA szerint a különböző múszakokra, illetve a szabadnapokra vonatkozó kérdésekre

Előzetes vizsgálatok szerint a változók kvázi normáleloszlásúaknak tekinthetők. 
adott pontszámok átlaga szignifikánsan $(\mathrm{p}<0,001)$ eltérö; a legrosszabb alvásminőséget és nappali tüneteket az éjszakai múszakot követő alvás kapcsán tapasztaltuk.

A post hoc tesztek szerint a nappali és délutáni műszak utáni alvászavar tünetei (1-3. kérdés) nem különböznek statisztikailag szignifikánsan, míg a nappali fáradtságra vonatkozó 3 kérdés esetén a nappali müszakban magasabbak a pontszámátlagok. A legjobb alvásról és pihentségről szabadnapok esetében számoltak be az ápolók (1. táblázat).

\section{A BSWSQ-H pszichometriai jellemzői, konvergens és diszkrimináns validitása}

A kérdőív belső reliabilitását jellemző Cronbach-alfa 0,95, ami igen jó. A kérdésekre adott válaszok közti korrelációk alapján a kérdőív latens struktúrája faktoranalízissel vizsgálható (a Kaiser-Meyer-Olkin-mérték 0,90; a Bartlett-teszt eredménye: $\mathrm{p}<0,001)$.

A faktoranalízis fókomponensmódszerrel nyert eredménye szerint négy l-nél nagyobb sajátértékkel rendelkező faktor extrahálódott, amelyek együttesen a variancia 70,1\%-át „magyarázzák”. Tartalmilag az első faktor a
BSWSQ-H első két kérdésblokkját tartalmazza, azaz az „elalvási nehézség és éjszakai ébrenlét” dimenzióját. A második faktor tömöríti a IV. és V. kérdésblokkból a „nappali múszakban és szabadidőben fáradtság, álmosság” kérdéseit. A harmadik faktor a „korai ébredés” dimenziója. Önálló faktorként jelenik meg az „éjszakai múszakban fáradtság, álmosság" dimenzió. A faktoranalízis eredménye szerint a BSWSQ-H kérdőív elsősorban az insomnia következményei szempontjából tárja fel a múszakok szerepét az alvásminóség vizsgálatában, és ebben is csak a nappali és éjszakai múszakok különülnek el.

Az alvásminőség vizsgálatára általánosságban használt AIS-teszt összesített pontszámával - a részmintán végzett vizsgálataink szerint - a BSWSQ-H összpontszáma szignifikáns $(\mathrm{p}<0,001, \mathrm{r}=0,609)$ korrelációt mutat, tehát a korábban magyar mintán igazolt insomniateszttel jó konvergens validitást mutat. Ha a faktorértékek és az AIS közti korrelációt vizsgáljuk, az „elalvási nehézség és éjszakai ébrenlét”, valamint a "nappali müszakban és szabadidőben fáradtság, álmosság” mutatnak erősen szignifikáns korrelációt az AIS-sel ( $\mathrm{p}=0,005$ és $\mathrm{r}=$ $0,358$, illetve $\mathrm{p}<0,001$ és $\mathrm{r}=0,472)$, ugyanakkor a „fáradtság, álmosság az éjszakai múszakban” és a „korai éb-

1. táblázat |Az insomnia tüneteinek műszakok szerint összehasonlítása

\begin{tabular}{|c|c|c|c|c|c|c|c|c|c|c|}
\hline \multirow[t]{2}{*}{$\begin{array}{l}\text { A „Bergen Váltott Műszak Kérdőív” } \\
\text { kérdései }\end{array}$} & \multicolumn{2}{|c|}{ Nappali múszak } & \multicolumn{2}{|c|}{ Délutáni múszak } & \multicolumn{2}{|c|}{ Éjszakai múszak } & \multicolumn{2}{|c|}{$\begin{array}{l}\text { Pihenőnap, } \\
\text { szabadnap }\end{array}$} & \multirow[t]{2}{*}{ F-érték* } & \multirow[t]{2}{*}{ Post hoc** } \\
\hline & Átlag & (szórás) & Átlag & (szórás) & Átlag & (szórás) & Átlag & (szórás) & & \\
\hline $\begin{array}{l}\text { 1. Milyen gyakran szükséges } 30 \\
\text { percnél hosszabb idő az elalváshoz } \\
\text { a lámpa lekapcsolását követôen? } \\
(\mathrm{n}=227)\end{array}$ & 1,28 & $(1,20)$ & 1,20 & $(1,23)$ & 1,44 & $(1,37)$ & 1,18 & $(1,13)$ & $\mathrm{F}_{2,44 ; 9,71}=7,36$ & $\begin{array}{l}\mathrm{E}>\mathrm{N} / \\
\mathrm{D}>\mathrm{P}^{* * *}\end{array}$ \\
\hline $\begin{array}{l}\text { 2. Milyen gyakran fordul elö, hogy } \\
30 \text { percnél hosszabb időt tölt ébren } \\
\text { a fó alvásidejében? }(\mathrm{n}=227)\end{array}$ & 1,35 & $(1,16)$ & 1,34 & $(1,20)$ & 1,51 & $(1,34)$ & 1,22 & $(1,09)$ & $\mathrm{F}_{2,47 ; 9,71}=7,36$ & $\mathrm{E} / \mathrm{N} / \mathrm{D}>\mathrm{P}$ \\
\hline $\begin{array}{l}\text { 3. Milyen gyakran fordul elö, hogy } \\
\text { több mint } 30 \text { perccel elóbb ébred, } \\
\text { mint szeretne, és nem tud } \\
\text { visszaaludni? }(\mathrm{n}=229)\end{array}$ & 1,38 & $(1,20)$ & 1,25 & $(1,19)$ & 1,53 & $(1,31)$ & 1,32 & $(1,18)$ & $\mathrm{F}_{2,64 ; 9,93}=7,79$ & $\mathrm{E}^{\prime}>\mathrm{N} / \mathrm{P} / \mathrm{D}$ \\
\hline $\begin{array}{l}\text { 4. Milyen gyakran fordul elö, hogy } \\
\text { alvás után nem érzi magát } \\
\text { megfelelően kipihentnek? }(\mathrm{n}=228)\end{array}$ & 2,07 & $(1,16)$ & 1,88 & $(1,18)$ & 2,48 & $(1,16)$ & 1,57 & $(1,16)$ & $\mathrm{F}_{2,83 ; 98,55}=69,60$ & $\mathrm{E}^{\prime}>\mathrm{N}>\mathrm{D}>\mathrm{P}$ \\
\hline $\begin{array}{l}\text { 5. Milyen gyakran szokott fáradt/ } \\
\text { álmos lenni munka közben? } \\
(\mathrm{n}=229)\end{array}$ & 1,78 & $(0,97)$ & 1,52 & $(1,00)$ & 2,20 & $(1,06)$ & & & $\mathrm{F}_{1,90 ; 53,45}=50,11$ & $E ́ \mathrm{E}>\mathrm{N}>\mathrm{D}$ \\
\hline $\begin{array}{l}\text { 6. Milyen gyakran szokott fáradt/ } \\
\text { álmos lenni szabadidejében } \\
\text { (munkaidőn kívül) munkanapjain? } \\
(\mathrm{n}=231)\end{array}$ & 1,76 & $(1,05)$ & 1,57 & $(1,04)$ & 2,10 & $(1,24)$ & & & $\mathrm{F}_{1,92 ; 32,48}=32,73$ & $\mathrm{E}^{\prime}>\mathrm{N}>\mathrm{D}$ \\
\hline $\begin{array}{l}\text { 7. Milyen gyakran szokott fáradt/ } \\
\text { álmos lenni pihenőnapokon/ } \\
\text { szabadság alatt? }(\mathrm{n}=441)\end{array}$ & & & & & & & 1,53 & $(0,92)$ & & \\
\hline
\end{tabular}

*Összetartozó mintás varianciaanalízis Huynh-Feldt-korrekcióval.

**Páronkénti összehasonlítás Bonferroni-korrekcióval („>” $=\mathrm{p}<0,05 ;$ „” = nem szignifikáns).

***É = éjszakai múszak esetén; $\mathrm{D}=$ délutáni múszak esetén; $\mathrm{N}=$ nappali múszak esetén; $\mathrm{P}=$ pihenőnap, szabadság alatt. 
redés” nem korrelálnak. A BSWSQ-H tehát az AIS-nél árnyaltabban (műszaktól függően jellemzi) az alvásminőséget.

A BSWSQ-H összpontszáma és a PSS-teszt összpontszáma közti korreláció szignifikáns $(\mathrm{p}<0,001, \mathrm{r}=0,554)$. Az AIS-sel összehasonlítva a korreláció kevésbé erős. A BSWSQ-H faktorait tekintve, a „korai ébredés” kivételével, a PSS összpontszáma mindegyik faktorral szignifikánsan korrelál. Ugyanakkor a PSS „megküzdés” dimenziójával csupán az „elalvási nehézség és éjszakai ébrenlét” faktor korrelál, míg a „stresszhelyzet, stresszelés” dimenziójával az „éjszakai müszakban fáradtság, álmosság" faktor. A BSWSQ-H többi faktora nem korrelál a PSS összetevőivel. Ez azt mutatja, hogy bár a PSS-sel mért észlelt stressz összefügg a BSWSQ-H alkalmazásával vizsgált alvásminőséggel, a kétféle eszköz nem ugyanazt méri, azaz a PSS-sel a diszkriminatív validitás megfelelő.

Kényelmi mintavétellel felvett kisebb mintán $(\mathrm{n}=22$; átlagéletkor 39,59 év, szórás 10,22 év; 1 férfi, 21 nő; 6 nappali munkarendben és 16 váltott múszakban dolgozó ápoló) vizsgáltuk a kérdőív időbeli stabilitását. A két kitöltés között 2 hét telt el, a Pearson-féle korrelációs együttható $0,999(\mathrm{p}<0,001)$.

\section{Az alvásminöséget és az ezzel kapcsolatos fáradtságot befolyásoló tényezők vizsgálata}

A továbbiakban az alvásminőséget (illetve insomniát) egyrészt a BSWSQ-H valamennyi kérdésének összesített pontszámával, másrészt az egyes múszakokra külön-külön összesített pontszámaival jellemezzük.

A nemek között nincs különbség a pontszámátlagok között ( $p>0,05)$. A kor előrehaladtával némileg javul az alvásminőség $(r=0,160 ; \mathrm{p}=0,017)$, az egészségügyben eltöltött évek számának azonban nem volt kimutatható hatása $(\mathrm{p}>0,05)$. Nem volt különbség aszerint, hogy melyik klinikai/kórházi osztályon dolgozik az ápoló, és aszerint sem, hogy milyen az éjszakai múszakban alkalmazott megvilágítás, továbbá hogy alkalmaz-e élénkítőszert (kávét, energiaitalt).

A munkarendek szabályossága alapján az ápolói munkarendeket három típusba soroltuk a Standard Shiftwork Indexben [7] szereplő kategóriák alapján. Szabálytalan müszakrend esetén rendszertelen a mûszakbeosztás, a múszakok nem ismétlődnek szabályosan és az egyéni kérésekhez sem igazodik. Flexibilis müszakrend esetén a rugalmas müszakrend szabálytalan ugyan, de a dolgozók előzetes igényeit figyelembe véve készül a müszakbeosztás. Szabályos műszakrend esetén a munkavégzési ciklusok szabályosan, állandó rendben ismétlődnek, amely alól csak néha lehet kivétel.

Az ANOVA szerint az alvásminőség és a nappali fáradtság erősen összefügg a munkarend szabályosságával ( $F=8,57 ; p<0,001)$. Ez külön-külön: a nappali, a délutáni és az éjszakai munkavégzésre, valamint a szabadnapokra vonatkozó kérdésekre is igaz a pontszámátlagok alapján. A post hoc tesztek szerint a szabályos és flexibilis munkarendúekkel szemben a legtöbb alvásprobléma a szabálytalan munkarendúeknél tapasztalható mindegyik műszak esetén. A szabályos és flexibilis munkarendüek átlagpontszámai nem különböznek egymástól szignifikánsan (1. ábra).

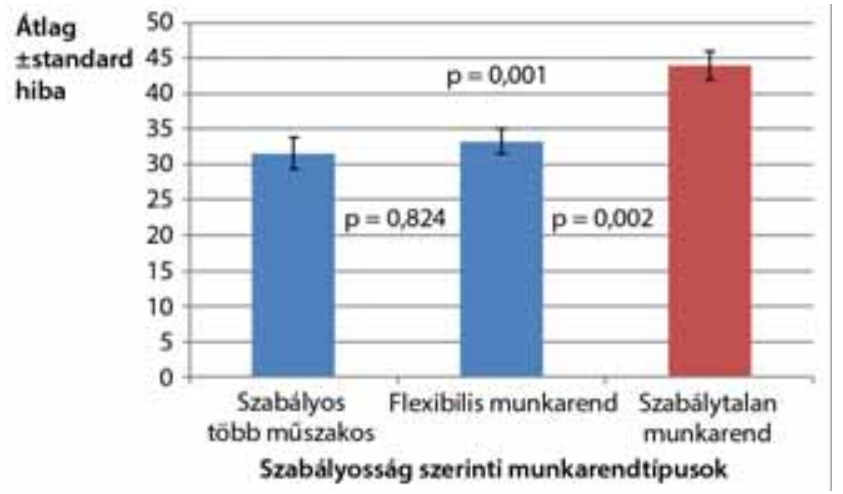

1. ábra Alvásminőség és nappali fáradtság a BSWSQ-H teszt összpontszáma alapján

Kutatásunk során felmértük, hogy milyen kronotípusba tartoznak a különböző múszakrendben dolgozó ápolók. A nappali munkarendben dolgozók átlagosan magasabb pontot kaptak az rMEQ-teszten ( $\mathrm{n}=36$; rMEQ: 20,33 pont; SD: 3,44), amely szerint ők reggeli típusúak, szemben az éjszakai $(\mathrm{n}=9 ; 14,22$ pont; $\mathrm{SD}: 3,56)$ és váltott müszakos munkarendben dolgozókkal ( $\mathrm{n}=146$; 18,73 pont; SD: 3,33, p<0,001), akik az alacsonyabb pontok alapján inkább esti típusúak.

\section{Megbeszélés}

Munkánkkal pótolni kívántuk a hiányt, amelyet a váltott müszakban dolgozók alvásminőségének felmérését szolgáló kérdőívek terén tapasztaltunk hazánkban. A Bergen Shift Work Sleep Questionnaire-t lefordítottuk magyarra, és elvégeztük a nyelvészeti validálást, majd megvizsgáltuk a pszichometriai jellemzőit. Eredményeink alapján a Bergen Váltott Múszak Alvás Kérdőív (BSWSQ-H) megfelel a szükséges pszichometriai előírásoknak, amely lehetővé teszi a diszkrét álmatlanság tüneteinek szisztematikus vizsgálatát különböző múszakokban. Eredményeinket összehasonlítottuk az eredeti norvég kérdőív validáló tanulmányában leírt eredményekkel [10], esetükben is az éjszakai müszak okozza a legtöbb panaszt, és a legjobb alvásminőségről szabadnapok esetén számoltak be. A nappali és délutáni műszak esetén is hasonló eredményeket kaptunk, mint a norvég mintán, azonban náluk az alvásproblémákra kérdező itemeknél a délutáni múszak esetén volt magasabb átlagpont, míg nálunk nem volt különbség a két múszak között. A faktoranalízis eredménye szerint a BSWSQ-H kérdőív elsősorban az insomnia következményei szempontjából tárja fel a müszakok szerepét az alvásminőség vizsgálatában, 
és ebben is csak a nappali és éjszakai műszakok különülnek el, míg Flo eredményei szerint a három müszak és szabadnap is külön faktorként jelenik meg.

A kérdőív alkalmazásával a különböző munkarendek alvásminőségre kifejtett hatását kívántuk felmérni, azaz összehasonlítottuk, melyik munkarendtípus megterhelőbb. A csak/fóként éjszakai müszakban dolgozók számoltak be a legrosszabb alvásminőségről az éjszakai müszakot követő alvás esetén. A több müszakos szabálytalan munkarendben dolgozók alvásminősége a legrosszabb a szabályos és flexibilis munkarenddel szemben, a nappali, a délutáni és éjszakai munkavégzés, valamint a szabadnapok és a kérdőív összesített pontjai esetén is. Ha valaki hosszú ideig dolgozik váltott múszakban, szervezete alkalmazkodik a megváltozott napirendhez [19], ezt igazoltuk, mivel az éjszakai munkarendben dolgozók kronotípusa esti típusú, míg a nappali munkarendú ápolóké reggeli típusú.

Kutatásunkat korlátozta, hogy a minta nem reprezentatív, és kevesen dolgoznak olyan munkarendben, amelyben délutáni múszak is szerepel (hazánkban föként a 12 órás, két mûszakos munkarend a jellemző). Munkánk folytatásaként a szabálytalan ápolói munkarendek okainak felderítését, továbbá a különböző szabályos munkarendek összehasonlítását tervezzük, az alvásminőségre és pszichoszomatikus panaszokra kifejtett hatásuk alapján.

Anyagi támogatás: A közlemény megírása, illetve a kapcsolódó kutatómunka anyagi támogatásban nem részesült.

Szerzői munkamegosztás: F. K.: A hipotézisek kidolgozása, a kérdőívcsomag elkészítése, nyelvi validálás, a vizsgálat lefolytatása, a kézirat megszövegezése. T. Á.: Statisztikai elemzések, a kézirat megszövegezése. F. N.: Szakirodalmi áttekintés, adatbázis készítése. M. Á.: Fordítás, kérdőív készítése. O. A.: A hipotézisek kidolgozása, a kézirat megszövegezése. A cikk végleges változatát valamennyi szerző elolvasta és jóváhagyta.

Érdekeltségek: A szerzőknek nincsenek érdekeltségeik.

\section{Irodalom}

[1] Weibel, L., Brandenberger, G.: Disturbances in hormonal profiles of night workers during their usual sleep and work times. J. Biol. Rhythms, 1998, 13(3), 202-208.

[2] Sanders, D. C., Chaturvedi, A. K., Hordinsky, J. R.: Melatonin: aeromedical, toxicopharmacological, and analytical aspects. J. Anal. Toxicol., 1999, 23(3), 159-167.

[3] Lee, C. Y., Chen, H. C., Meg Tseng, M. C., et al.: The relationships among sleep quality and chronotype, emotional disturbance, and insomnia vulnerability in shift nurses. J. Nurs. Res., 2015, 23(3), 225-235.
[4] Kikuchi, ., Ishii, N.: The relationship between self-awareness of fatigue symptoms and working conditions in female nurses. Sangyo Eiseigaku Zasshi, 2015, 57(5), 230-240.

[5] Yazdi, Z., Sadeghniiat-Haghighi, K., Javadi, A. R., et al.: Sleep quality and insomnia in nurses with different circadian chronotypes: morningness and eveningness orientation. Work, 2014, $47(4), 561-567$.

[6] Purebl, Gy., Bánki, M. Cs., Novák, M.: Insomnia - diagnostic and therapeutic guide. [Insomnia - diagnosztikus és terápiás útmutató.] Pszichiátriai útmutató. Medition Kiadó, Budapest, 2010. [Hungarian]

[7] Barton, J., Spelten, E., Totterdell, P., et al.: The Standard Shiftwork Index: a battery of questionnaires for assessing shiftworkrelated problems. Work Stress, 1995, 9(1), 4-30.

[8] Fusz, K., Kovács, K., Kìés, Zs., et al.: Effects of nursing shift schedules using Standard Shift Work Index - pilot study. [Ápolói múszakrendek hatásainak vizsgálata Standard Shiftwork Index alkalmazásával - pilot vizsgálat.] Nővér, 2014, 27(4), 3-10. [Hungarian]

[9] Flo, E., Pallesen, S., Mageroy, N., et al.: Shift work disorder in nurses - assessment, prevalence and related health problems. PLoS ONE, 2012, 7(4), e33981.

[10] Flo, E., Bjorvatn, B., Folkard, S., et al.: A reliability and validity study of the Bergen Shift Work Sleep Questionnaire in nurses working three-shift rotations. Chronobiol. Int., 2012, 29(7), 937-946.

[11] Buysse, D. J., Reynolds, C. F. 3rd, Monk, T. H.: The Pittsburgh Sleep Quality Index: a new instrument for psychiatric practice and research. Psychiatry Res., 1989, 28(2), 193-213.

[12] Soldatos, C. R., Dikeos, D. G., Paparrigopoulos, T. J.: Athens Insomnia Scale: validation of an instrument based on ICD-10 criteria. J. Psychosom. Res., 2000, 48(6), 555-560.

[13] Johns, $M$. W.: A new method for measuring daytime sleepiness: The Epworth Sleepiness Scale. Sleep, 1991, 14(6), 540-545.

[14] Novák, M.: Sleep disorders and quality of life. Doctoral dissertation. [Alvászavarok és életminőség. Doktori Értekezés.] Semmelweis Egyetem, Budapest, 2004. [Hungarian]

[15] Simon, P., Köteles, F., Bódizs, R., et al.: Survey of subjective sleep quality: Hungarian validation of Groningen Sleep Quality Scale. [A szubjektív alvásminőség kérdőíves vizsgálata: a Groningen Alvásminőség Skála hazai validálása.] Mentálhigiéné és Pszichoszomatika, 2009, 10(3), 249-261. [Hungarian]

[16] Stauder, A., Konkoly Thege, B.: Characteristics of the Hungarian version of the Perceived Stress Scale (PSS). [Az Észlelt Stressz Kérdőív (PSS) magyar verziójának jellemzői.] Mentálhigiéné és Pszichoszomatika, 2006, 7(3), 203-216. [Hungarian]

[17] Horne, J. A., Ostberg, O.: A self-assessment questionnaire to determine morningness-eveningness in human circadian rhythms. Int. J. Chronobiol., 1976, 4(2), 97-110.

[18] Urbán, R., Magyaródi, T., Rigó, A.: Morningness-eveningness, chronotypes and health-impairing behaviors in adolescents. Chronobiol. Int., 2011, 28(3), 238-247.

[19] Kim, H. I., Jung, S. A., Choi, J. Y., et al.: Impact of shiftwork on irritable bowel syndrome and functional dyspepsia. J. Korean Med. Sci., 2013, 28(3), 431-437. 